\title{
The use of lithotomy by missionary surgeons in nineteenth-century China
}

\author{
$\mathrm{L} \mathrm{Fu}$ \\ Formerly Consultant Orthopaedic Surgeon, Hong Kong
}

\begin{abstract}
Modern medicine in China owes its origins to Anglo-American medical missionaries who introduced Western medicine into China in the early nineteenth century. In 1835 the first medical missionary to China, the Reverend Dr Peter Parker, founded the Canton Ophthalmic Hospital where he pioneered lithotomy and other surgical operations for Chinese patients. This paper chronicles the subsequent development of surgery for bladder stones at that institution by $\mathrm{Dr}$ Parker, Dr John Kerr and their successors. Modifications of technique and improvisations by these dedicated practitioners under less-than-optimal conditions and in an unfamiliar population, provide a unique and interesting insight into medicine of the time as practiced in China.
\end{abstract}

Correspondence to $L F u$,

Flat C, 2/Floor, South Hillcrest, 3 Tuen Kwai Road,

Tuen Mun, Hong Kong

tel. +85297084908

e-mail

dr.louisfu@yahoo.com.hk

KEYWORDS China, bladder stones, lithotomy, missionary doctors, Peter Parker, John Kerr

DECLARATION OF INTERESTS No conflict of interests declared.

\section{THE INTRODUCTION OF MODERN MEDICINE INTO CHINA}

Rev. Dr Parker opened China at the point of a lancet when Western cannon could not heave a bar.'

The Reverend Dr Beadle American Board of Commissioners for Foreign Missions

On 4 June 1834, a Yale graduate, the Reverend Dr Peter Parker, MD, DD (1804-1888) of Framingham, Massachusetts travelled from New York to Canton where he landed on 26 October 1834 (Figure I). ${ }^{2}$ Sent to China under the auspices of the American Board of Commissioners for Foreign Missions with the aim of using medicine to introduce Christianity to the Chinese, Parker opened the first missionary hospital in China (the Ophthalmic Hospital) on 4 November 1835.3.4 This hospital was situated in the 'Thirteen Factories' district, an area outside Canton where European and American merchants resided in virtual isolation from the Chinese. ${ }^{5}$ In his first quarterly report for the period 5 November 1835 to 4 February 1836 Parker wrote: ${ }^{6}$

The factory Number 7 in Fung Ta Hong on San Tao Lan Street [Hog Lane] was rented of Howqua, [Wu How-kuan] the senior member of the co-hong [guild of Chinese merchants] at $\$ 500$ per annum. Its retired situation, and direct communication with a street, so that patients could come and go without annoying foreigners by passing through their hongs [business houses], or excite the observation of natives by being seen to resort to a foreigner's house, rendered it a most suitable place for the purpose. Besides a large room in the second storey, where 200 may be

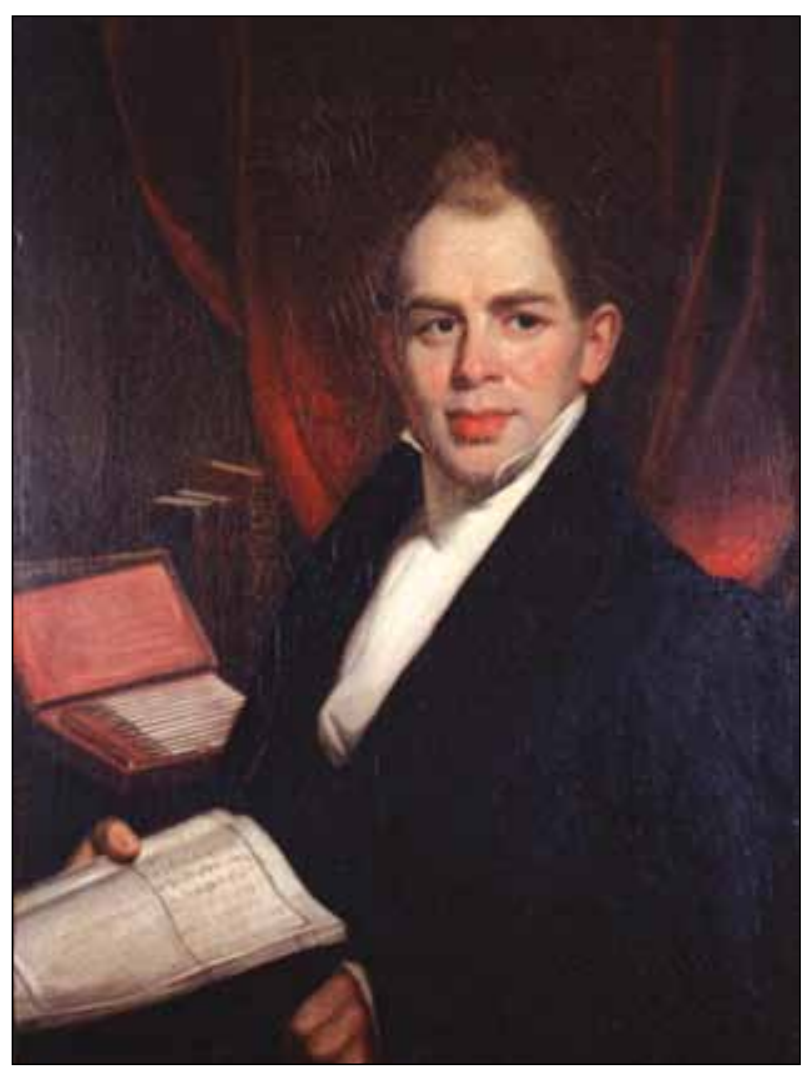

FIGURE I Rev Dr Peter Parker, MD, DD (I804-1888). Yale University, Harvey Cushing/John Hay Whitney Medical Library.

comfortably seated and prescribed for, the house can afford temporary lodgings for at least 40 patients... Thursdays are set apart for operations for cataracts, entropia, pterygia, and other surgical cases. 
On the ground floor there were a few rooms for domestic purposes and a large stone paved hallway. Colour portraits of patients before and after surgery decorated the walls on the first floor. One small apartment served as the consultation room, while another was fitted out as the dispensary. The operating room and three other rooms for inpatients were housed on the top floor. ${ }^{7}$

Parker's aims were firstly to 'enlighten' China in the science of medicine and surgery, and secondly, to spread Christianity among the vast population. Through successfully treating patients, he demonstrated to the Chinese the great value of hospitals, the advances of medical science and its practical benefits. This unselfish and generous service also helped win over Chinese hearts and minds, thereby paving the way for the introduction of Christianity. ${ }^{8}$ The hospital was an immediate success. Generous donations were received from Western missionaries and merchants in Canton, amounting to $\$ 1,800$ by the end of the first year, ${ }^{9}$ while costs were $\$ 454.84$. Parker himself received no remuneration.

The hospital was known in Chinese as $\mathrm{Pu} \mathrm{Ai}$ I-yuan, literally 'Hospital of Universal Love., ${ }^{5,10}$ As its fame spread, patients, from beggars to members of the Imperial household flocked to it from all parts of Canton. Parker came to be admired by all sections of Chinese society including the haughty official class and the initially sceptical gentry." In those days of strained relations between China and the West, the hospital played an important role in improving mutual understanding between foreigners and the Chinese people. Parker was the first surgeon to perform upon Chinese patients the operations of amputation of limbs, extraction of cataracts, excision of tumours, and lithotomy. He also introduced ether anesthesia into China in 1847. This paper documents his experience with the operation of lithotomy for bladder stone..$^{5,12}$

\section{THE EVOLUTION OF LITHOTOMY}

I cut thirty of ye stone in one year and all lived, and afterwards cut four and they all died ${ }^{13}$

Thomas Hollyer, lithotomist to St Thomas's Hospital, London

Of the three oldest elective surgical operations in civilisation - circumcision, trepanation, and cutting for the stone, the latter may be considered the most ancient procedure for the cure of a specific condition. ${ }^{14}$ The evolution of lithotomy is mired with intrigue, jealousy, and dishonest dealings between lithotomists - quacks or qualified - and their patients. ${ }^{15}$

Until the twentieth century, bladder stone was one of the most prevalent disorders in males, especially among children and adolescents of the lower classes. Climate, water intake, and diet have all been implicated in the aetiology, but in recent years, as a result of improved living conditions, the incidence of primary bladder stone has declined, most notably in children. ${ }^{16,17}$ There are essentially three approaches to lithotomy: the perineal, the suprapubic and the transurethral.

\section{Perineal lithotomy}

Prior to the anaesthetic era, perineal lithotomy tested the skill and dexterity of the surgeon and the courage and resilience of the patient. Celsus described extracting a bladder stone in a child by cutting the skin over the stone that was pressed against the perineum by a finger in the rectum (Figure 2). ${ }^{18}$ This simple procedure was called 'cutting on the gripe' or the 'lesser operation'. For adults, a more complicated procedure, 'cutting on the staff', was developed in the sixteenth century by Marianus Barolitanus. ${ }^{19,20}$ From the mid-sixteenth to the eighteenth century in Europe, barber-surgeons and itinerant quacks dominated lithotomy. The most famous of these colourful and controversial characters was Jacques de Beaulieu, better known as Frère Jacques. ${ }^{14,15}$

Lithotomy evolved into a scientific procedure in the hands of William Cheselden of St Thomas's Hospital. ${ }^{21,22}$ His technique, based on anatomical study, involved cutting through the membranous urethra, thus avoiding injury to the venous plexuses. ${ }^{15}$ It has been claimed that he performed the procedure in thirty seconds and that his mortality rate was less than $10 \% .^{21}$

Robert Liston of the Edinburgh Royal Infirmary also stressed the advantage of operative speed. ${ }^{23}$

There can be no apology for the patient being longer than a very few minutes under the operation. Should there be but one or two stones of a moderate size (under the size of a hen's egg), the incision and extraction should not occupy more than two or three minutes at most. ${ }^{24}$

\section{Suprapubic lithotomy}

Due to the difficulties inherent in extracting a large stone from a child through perineal lithotomy in 156I, Pierre Franco was forced to use the suprapubic approach. ${ }^{25}$ This involved entering the bladder via an abdominal incision just above the symphysis pubis. John Douglas of Westminster Hospital revived this operative procedure in December 1719, calling it Lithotomia Douglassiana. ${ }^{26}$ William Cheselden published a treatise on this 'high operation' for stone in 1723, but when Douglas accused him of plagiarism ${ }^{27}$ he reverted to the perineal method. ${ }^{28}$ Suprapubic lithotomy became more popular with the advent of general anaesthesia. 


\section{Lithotrity}

The extraction of moderate-sized bladder stones via the urethra after crushing them into small fragments was said to have been practiced by the ancient Egyptians. They forcibly dilated the urethra with a hollow wooden tube which was pushed against the stone before it was sucked out. ${ }^{28}$

In 1817 the French surgeon Jean Civiale invented the lithotriteur for drilling and fragmenting the stone. ${ }^{30}$ Over the next I50 years, new instruments were developed until lithotrity became obsolete in the late 20 th century.

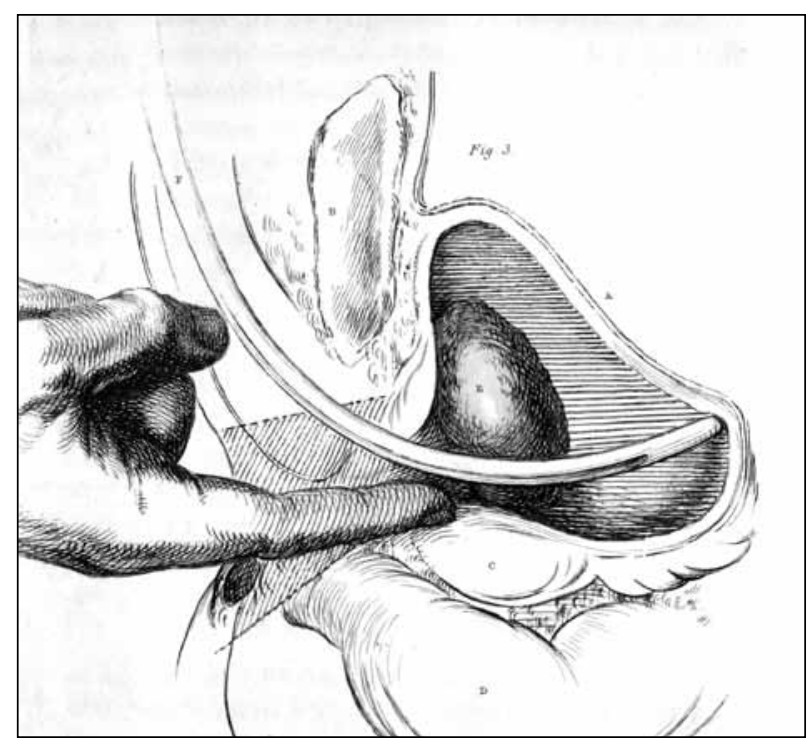

FIGURE 2 Technique of localising bladder stone as a prelude to perineal lithotomy. The finger in the rectum was used to press the stone against the perineum, which was then incised. (Image from Charles Bell's Great Operations of Surgery 182 ${ }^{55}$ courtesy of The Royal College of Surgeons of Edinburgh.)

\section{BLADDER STONES IN PRE-MODERN CHINA}

There are three sorts of diseases to escape any of which a man has good title to destroy himself; the worse of these is stone in the bladder. ${ }^{31}$

Pliny the Elder, Historia Naturalis

There is no obvious explanation for the preponderance of urinary stones in the people of Canton (provincial capital of the southern coastal Kwang-tung) compared to the rest of China. ${ }^{32}$ Western-style missionary hospitals had been established in the five 'Treaty Ports' (Shanghai, Canton, Ningpo, Fuchow and Amoy) after the First SinoBritish War (Opium War) of 1839-1842.

During the time Parker was in charge of the Canton hospital, he performed thirty two lithotomies, the last in February $1852 . .^{33}$ In his seventh quarterly report for the term ended December 1837, there were three cases of

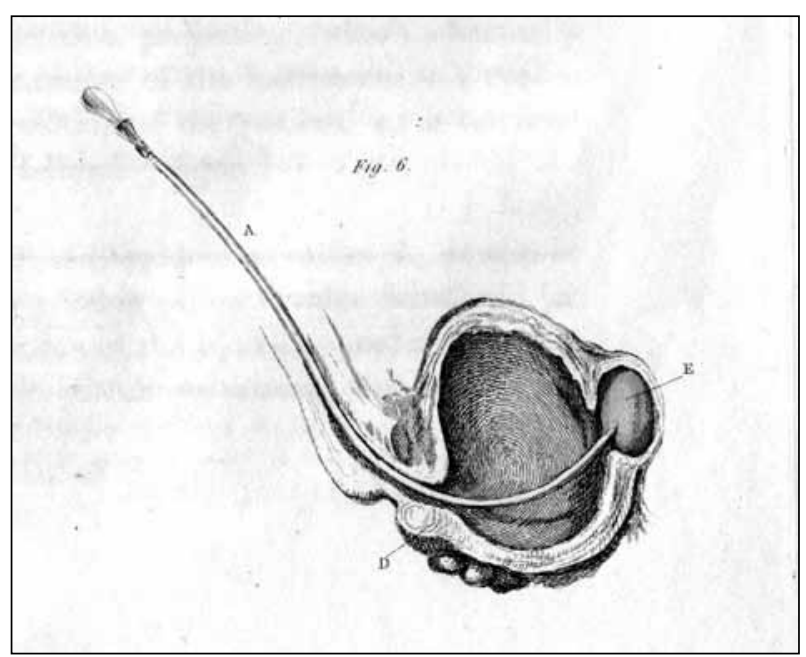

FIGURE 3 Technique of 'sounding' for stone. A metal sound passed into the urethra was used to localise the stone in the bladder, the diagnosis confirmed by the click heard on abdominal auscultation when the sound touched the stone. (Image from Charles Bell's Great Operations of Surgery 182155 courtesy of The Royal College of Surgeons of Edinburgh.)

urinary calculus among 4,575 patients ${ }^{34}$ and for the two years, 1838 and 1839 , there were only three cases. ${ }^{35,36}$

The following reports marked a new era in the Ophthalmic Hospital as well as in Chinese medical history. Parker's thirteenth report of the hospital from I January to I July 1845 is worthy of extensive quotation: ${ }^{37}$

During the period now under consideration 6,209 patients have been received, and an aggregate of 18,257 since the commencement of the institution in October $1835 \ldots$ from the beggar to the highest functionary under the imperial government... a number of successful cases of lithotomy are given in full. The more interesting as they are probably the first instance, so far as is known, since the foundation of the empire. When the missionary aim of these labors is borne in mind, neither the profession nor others will deem misplaced the moral treatment, in connection with the physical and surgical... The stone that has caused pain for years, not less distressing than the rack, has been in as many minutes extracted and in an equal number of days followed with perfect recovery, yet all these are but subordinate to the aim, instrumentally to improve spiritual blessings, that run parallel and commensurate with man's immoral existence... While rejoicing that these labors are appreciated and approved by the most enlightened, devoted and Christian communities, and by the highest personages civil and ecclesiastical of the age, the deepest consolation is in the humble hope of the approbation and blessing now, and the future reward of that Saviour whose kingdom we devoutly desire to see established in China. 
Number II 205. July 17th 1844. Lithotomy. Aged 35, afflicted with stone had long been under notice. A year previous he was an inmate of the hospital, when the stone was grasped and broken into two by lithotrity, but too hard to be broken down... Lithotomy was resorted to. For weeks previously he was under moral and physical preparation for the operation, being supplied with the Gospels and Christian books in Chinese, with the desire that he would acquaint himself with their contents and become a worshipper of the God they reveal...The stone in two pieces measured $31 / 2$ inches and $51 / 2$ inches, weighed one ounce and one drachm, and was extracted by the lateral operation. All was favorable... in nine days the water ceased entirely to flow through the wound, and in eighteen days he was perfectly well.

The following year operations of a similar nature were performed: ${ }^{37}$

Number 16564. May 13th 1845. Urinary calculus of peculiar character. Aged 30 had suffered from urinary calculus for twenty-three years! Having been under preparatory treatment for some time, assisted by... and my pupils, the stone was this day extracted by the lateral operation. It measured $4 \frac{1}{2}$ by $51 / 2$ inches in circumference, and weighed $21 / 2$ ounces... the patient bore the operation with heroic fortitude, not seeming to notice the incisions, and remarked shortly after that he had not suffered much. 'I feel liberated'. He appeared truly grateful. Reminding him of the divine goodness, he was urged to render his thanks to God. He replied 'many thanks to the doctor'... But this was not the object, he was again desired to render thanks to God, of him he seemed to have very imperfect conceptions. It was remarked to him that to extract the calculus was comparatively easy, to extirpate the stony heart and give the heart of flesh, is the work of the spirit of the Almighty God.

June 6th, the wound was perfectly healed, and the patient in excellent spirits, and had loss very little flesh. Thus in twenty-three days he was completely relieved of his distressing calamity of twenty-three years... No operations in this hospital have ever excited so much attention and surprise on the part of intelligent Chinese and officers of the Government.

Number 1516I. December 1845. Stones in the bladder, aged 21 . Had been afflicted by this distressing disease for fourteen years! During this period he had not been able to sleep in a recumbent posture, and often in severe paroxysms, he appeared more like a delirious than a sane person. Two stones were extracted... The second day after the operation it was discovered that the rectum had been wounded... the sphincter muscles were immediately divided as in cases of complete fistula... The patient became for a time emaciated, but now enjoys robust health again, only inconvenienced by a very small fistula in the membranous urethra. Two stones were also extracted from him... since his convalescence he has been in the employ of the Rev. Dr Bridgman, from whom he still receives instruction in the knowledge of the Gospel.

In June 1840, due to open war between the British and the Chinese, Parker left for America on furlough. He addressed the US Congess, lectured in medical schools, theological seminaries, and at public meetings, pleading his cause and asking for donations. ${ }^{38}$ Crossing the Atlantic to the UK in April I84I, he was welcomed as a celebrity. In Parker's words:

Nowhere more than in Edinburgh was a sincere interest in this cause manifested... A public meeting was held there, attended by the chief citizens of the place, and an efficient committee appointed to carry out the designs of the meeting... Intelligence has been received of the organization of a society auxiliary to that in China, by which a circular has been issued and widely circulated, appealing to the Christians of Scotland and England in behalf of our object. ${ }^{39}$

Parker wanted to stir up interest among friends of the Christian missions. He first applied for aid to carry out his plans from Dr John Abercrombie (Vice President of the Royal Society of Edinburgh and a prominent physician). A meeting at the Waterloo Hotel in Edinburgh was presided over by the Lord Provost. ${ }^{5}$ Dr Abercrombie was appointed President of the Edinburgh Association for Sending Medical Aid to Foreign Countries, which two years later became the Edinburgh Medical Missionary Society. ${ }^{38}$ Other members of the committee included William Alison, Professor of Physic, James Syme, Professor of Surgery, and the President of the Royal Bank of Scotland, John Thompson, who was treasurer. ${ }^{3}$ Parker returned to China in October 1842, and soon after proceeded to Canton and reopened the hospital there. ${ }^{40}$

\section{ANAESTHESIA}

Ether anaesthesia was introduced into China by Parker in 1847. ${ }^{10} \mathrm{He}$ obtained a supply of sulphuric ether from Boston, the apparatus of Dr Charles Thomas Jackson (a chemist who claimed to have discovered ether's anaesthetic properties), and a letter of instruction from him. ${ }^{5}$ On 24 November 1849, lithotomy was performed under chloroform anaesthesia, the first time this had been used in China. The drug came from New York, with a pamphlet by Professor James Young Simpson about this new anaesthetic agent. ${ }^{5,33}$

The ordinary Chinese person knew little of the outside world, and nothing about modern surgery. The ability of 
foreign surgeons to cure painful diseases, restore sight to the blind and remove large tumours by methods unknown to indigenous physicians, soon became known throughout the nation. As xenophobia and hostilities to foreigners decreased, more patients applied for treatment. Parker's connection with the American Board was severed in 1847, though he continued to work at the hospital until 1855 , when diplomatic duties with the United States Legation engaged his full attention. ${ }^{2,3}$

\section{DR JOHN GLASGOW KERR}

Dr John Glasgow Kerr MD (I824-190I) of Duncansville, Ohio, a graduate of Jefferson Medical College, was sent to China by the American Presbyterian Mission (Figure 4). ${ }^{41,42}$. In May 1855 he was asked to take charge of the hospital. ${ }^{5,42}$ Kerr performed the first successful lithotrity in China in 1855, but he considered lithotomy safer because of the pain and sometimes fatal bacteraemia associated with lithotrity. ${ }^{32}$

In December 1856, the hospital was burned down due to hostilities that eventually led to the Second SinoBritish War of 1856-1858. The practice was re-established in a new building, and the hospital's name was changed to PokTsai (literally 'Diffusive Benevolence') in January 1859.5

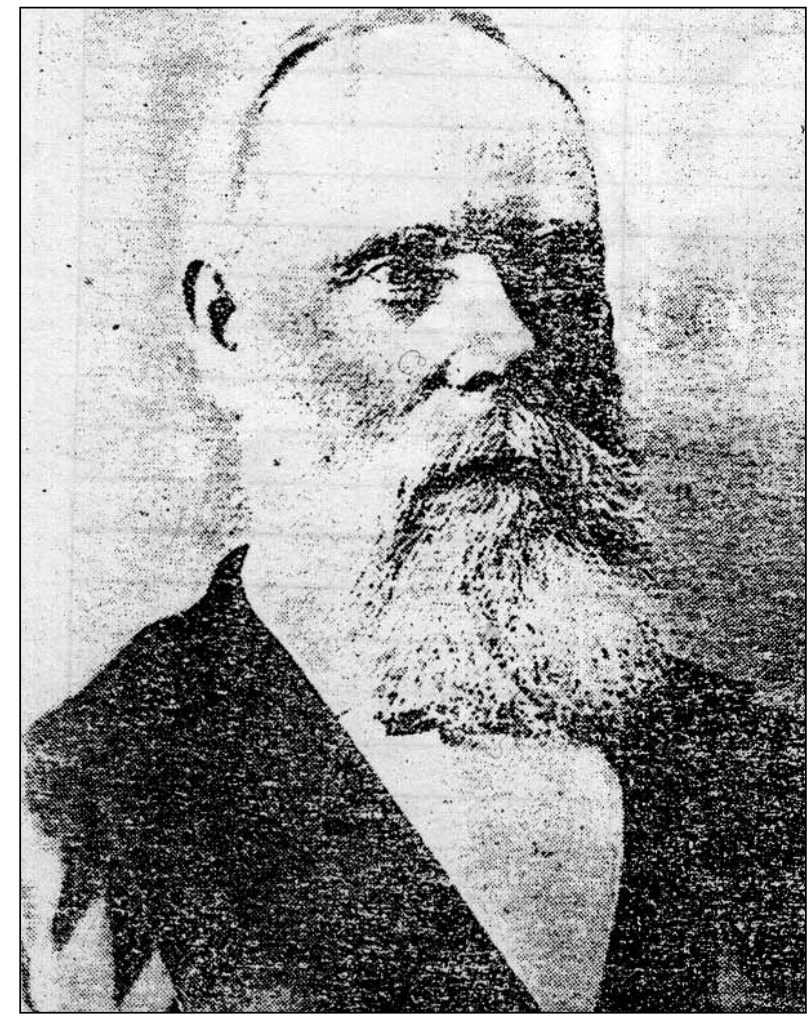

FIGURE 4 Dr John Glasgow Kerr. (From the author's own collection.)
From 1888, Dr John Myers Swan MD (1860-1919) of Glasgow, Ohio became Kerr's assistant. ${ }^{43}$ and they performed 963 perineal and 50 suprapubic lithotomies, together with 120 lithotrities. Age, physical condition of the patient, size and density of the stone, and the condition of the urinary tract influenced the choice of operation. ${ }^{44}$ Thirty per cent of the patients were children under ten years old. The procedures had a combined mortality rate of $9.5 \%$.

From infancy to puberty, perineal lithotomy gave the best results. The operation time was from three to ten minutes, recovery was generally uneventful, the wound closing in one to two weeks and fistula, stricture and sterility were almost unknown. ${ }^{45}$

\section{LEGACY OF THE MEDICAL MISSIONS}

With the Canton Hospital already a going concern, medical missionaries began work in Hong Kong, Shanghai, Amoy, Foochow and Ningpo. From such humble beginnings, medical schools, large well-equipped hospitals, and various auxiliary organisations have sprung up throughout China. ${ }^{46}$ The efforts of these pioneers were augmented by successive generations of farseeing men and women, who devoted their lives to the spread of their religion, and to the development of the highest standards of medicine, all motivated by Christian ideals with little thought of personal gain. ${ }^{47,48}$

Some Chinese historians, especially Marxists, have viewed the introduction of Western medicine into China as one of the means of 'invasion by Anglo-American Imperialism under the banner of medicine'. ${ }^{49}$ Scathing attacks were made against the American missions in general, and Parker in particular as 'wolves in sheep's clothing, ${ }^{50,51}$ The pendulum has swung the other way with the passage of time. Most contemporary observers now agree thatWestern medicine as a scientific discipline has been of undisputed benefit to the advancement of knowledge in China. ${ }^{52,53}$ Objective reappraisal of the role of the medical missionaries suggests that their contribution was a valuable one for the development of medicine in China. ${ }^{54}$

\section{REFERENCES}

I Balme H. China and modern medicine, a study in medical mission development. London: United Council for Missionary Education; 1921.

2 Stevens GB, Marwick WF. The life, letters and journals of the Rev. and Hon. Peter Parker, M. D., missionary, physician and diplomatist, the father of medical missions and founder of the Ophthalmic Hospital in Canton. Boston: Congregational Sunday-School and Publishing Society; 1896.

3 Gulick EV. Peter Parker and the opening of China. Cambridge: Harvard University Press; 1973.

4 Bartlett CJ. Peter Parker, the founder of modern medical missions. JAMA 1916; 67: 407-II.

5 Cadbury WW, Jones $\mathrm{MH}$. At the point of a lancet: one hundred years of the Canton Hospital, 1835-1935. Shanghai: Kelly andWalsh; 1935. 
6 Parker P. Ophthalmic Hospital at Canton: first quarterly report, from the 4th of November 1835 to the 4th of February 1836 Chinese Repository Volume IV. Canton. From May 1835 to April 1836. I836; 46I-73.

7 Downing CT. The fan-qui in China 1836-7 vol. II. London: Henry Colburn; 1838

8 Parker P. Statements respecting hospitals in China, preceded by a letter to John Abercrombie, MD, VPRSE, by Rev. P. Parker MD, medical missionary of the American Board of Foreign Missions in China. Glasgow: James MacLehose; 1842.

9 Parker P. Ophthalmic Hospital at Canton: fourth quarterly report, for the term ending on 4th November 1836. Chinese Repository Volume V. Canton. From May 1836 to April I837. 1837: 323-32.

10 Hume EH. Peter Parker and the introduction of ether anaesthesia into China.J Hist Med Allied Sci 1946; I:670-74.

II Thomson JC. Obituary: Rev. Dr Peter Parker MD, first medical missionary to China. Ch Med Missionary J I888; 2:169-72.

12 Tucker SW. The Canton Hospital and medicine in nineteenth century China 1835-1900. [Ph. D. Thesis] Indiana University;1982. Ann Arbor, Michigan; University Microfilms International; 1990.

13 Newman A. The illustrated treasury of medical curiosa. New York: McGraw-Hill; 1988.

14 Ellis H.A history of surgery. London: Greenwich Medical Media Ltd.; 200 I.

15 Wangensteen $\mathrm{OH}$, Wangensteen SD. The rise of surgery from empirical craft to scientific discipline. Minneapolis: University of Minnesota Press; 1978.

I6 Bailey H, Love RJM, Rains AJH, Capper WM, editors. Bailey and Love's short practice of surgery. I4th ed. London: HK Lewis; 1968.

17 Lonsdale K. Human stones. Science 1968; 159: II99-1207.

I8 Celsus AC. SpencerWG (translator). Loeb classical library: De medicina book VII. Cambridge, Massachusetts: Harvard University Press; 1953.

19 Riches E. The history of lithotomy and lithotrity. Ann R Coll Surg Engl 1968; 43:185-99.

20 Greenfield JA [Groenveldt JA]. A complete treatise of the stone and gravel comprising in origin, symptoms, best way of easing, true method of cutting, and divers remarkable histories of cutting many cruelly afflicted patients, with an ample discourse on lithontriptick or stonebreaking medicines. London: R Smith and B Lintott; 1710.

21 Power D'A.William Cheselden. Br J Surg 1915; 3:157-60.

22 Cope Z. William Cheselden 1688-1752. Edinburgh and London: E \& S Livingstone; 1953.

23 Miles A. The Edinburgh school of surgery before Lister. London: A \& C Black Ltd; 1918.

24 Liston R. Remarks on the operation of lithotomy. Edinb Med Surg I 1825; 23: 26-28.

25 Murphy LJT. History of urology. Springfield, Illinois: Charles C Thomas; 1972

26 Douglas J.An account of the new method of cutting the stone. Phil Trans Roy Soc Lond I 722; 32: 83-88.

27 Garrison FH. An introduction to the history of medicine. 4th ed. Philadelphia:WB Saunders; 1929.

28 Cheselden W. A treatise on the high operation for the stone. London: John Osborne; 1723.

29 Murphy LJT. Self-performed operations for stone in the bladder. $\mathrm{Br}$ J Urol 1969; 4I: 515-29.

30 Civiale J. Sur la lithotritie ou broiment de la pierre dans la vessie. Arch Gen Med 1826; 10: 393-419.

31 Pliny the Elder. Beagon M (translator). Historia naturalis liber septi. New York: Oxford University Press; 2005.

32 Kerr JG.Vesical calculus in Canton Province, China, including the personal experience of 894 operations. Ch Med Missionary J I894; 8:104-16.

33 Thomson JO. Urinary calculus at the Canton Hospital, Canton, China. Surg Gynaecol Obstet 1921; 32:44-55.

34 Parker P.Ophthalmic Hospital at Canton: seventh report, being for the term ending the 3Ist December 1837. Chinese Repository. Volume VI. Canton. From April 1837 to May 1838. 1838: 433-45.

35 Parker P. Ophthalmic Hospital at Canton: the eighth report including the period from January Ist to June 30th 1838. Chinese Repository Volume VII. Canton. From May 1838 to April 1839. 1839: 92-106.
36 Parker P.Tenth report of the Ophthalmic Hospital, Canton, being for the year 1839. Chinese Repository Volume VIII. Canton. From May I839 to April I840. 1840: 628-39.

37 Parker P.Thirteenth report of the Ophthalmic Hospital at Canton, including the period from the Ist January 1844 to the Ist July 1845. Chinese Repository. Volume XIV. Canton. From January to December 1845. 1845: 449-64.

38 Young TK.The William Osler Medal essay.A conflict of professions: the medical missionary in China, 1835-1890. Bull Hist Med 1973; 47: 250-72.

39 Parker P. Report of the Medical Missionary Society containing an abstract of its history and prospects, and the report of the hospital at Macao for I84I-42; together with Dr Parker's statement of his proceedings in England and the United States in behalf of the Society. Chinese Repository. Volume XII. Canton. From January to December 1842. 1842: I88-206.

40 Parker P. Twelfth report of the Ophthalmic Hospital at Canton, from 2 Ist November 1842 to December 3Ist 1843. Chinese Repository. Volume XIII. Canton. From January to December 1844. 1844: 30I-20.

41 Selden CC. Life of John G. Kerr. Ch Med J 1935; 49:366-68.

42 Kerr JG. History of the Medical Missionary Society's Hospital, Canton. Ch Med Missionary J 1896; 10:55-7, 95-98.

43 Thomson JO. Lithiasis at the Canton Hospital. Ch Med J I921;35: 347-68.

44 Thomson JC. Calculus in China. Ch Med Missionary J I 890; 4: I I9-28.

45 Swan JM. Some remarks on the surgical treatment of urinary calculi. Ch Med J 1905; 19:131-33.

46 Wong KC, Wu LT. History of Chinese medicine, being a chronicle of medical happenings in China from ancient times to the present period. 2nd ed. Shanghai: National Quarantine Service; 1936.

47 Wong KC. Lancet and Cross: biographical sketches of fifty pioneer medical missionaries in China. Shanghai: Council on Christian Medical Work; 1950: p. ix-xi.

48 Latourette KS. A history of Christian missions in China. London: Society for Promoting Christian Knowledge; 1929.

49 Chen PH. Chung-kuo I-hsueh Shih [History of Chinese medicine]. Shanghai: Commercial Press; 1936. (In Chinese).

50 Wong KC. How Parker used medicine to invade China. Ch J Med Hist 195I; 3:I-6. (In Chinese).

5I Wong KC. Historical facts on the invasion of China by American imperialism. Peking Union Med Coll Bull 1954: 34-35. (In Chinese)

52 Choa GH. 'Heal the sick' was their motto: the Protestant Medical Missionaries in China. Hong Kong:The Chinese University of Hong Kong Press; 1990.

53 Qi X. American missionaries in recent Chinese history. Beijing: Beijing University Press; 2003. (In Chinese)

54 Pfister LF. In the eye of a tornado: lessons to be learned from critiques of Christian missionaries. In: Ching Feng: $A$ journal on Christianity and Chinese religion and culture, special issue for the Bicentennial of Robert Morrison's arrival in China. Hong Kong: Christian Study Centre on Chinese Religion and Culture; 2007: p. 9I-II6.

55 Bell C. Great operations of surgery. Trepan, Hernia, Amputation, Aneurism, and Lithotomy. London: Longman, Hurst, Rees et al; I82I. 